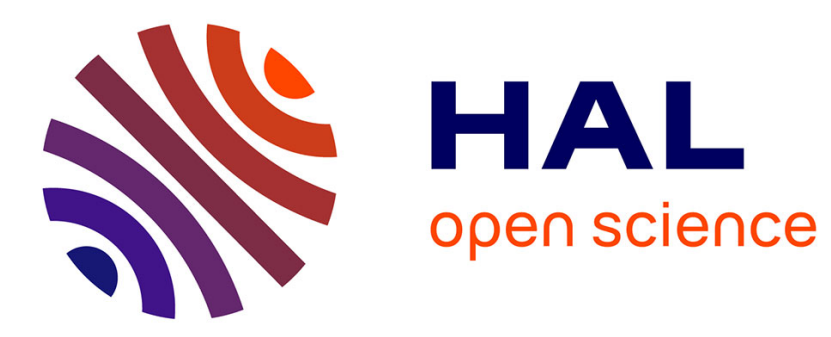

\title{
Hayes-Conroy J. (2014) Savoring Alternative Food: School Gardens, Healthy Eating, and Visceral Difference, New York, Routledge, 207 p \\ E. Melanie Dupuis
}

\section{To cite this version:}

E. Melanie Dupuis. Hayes-Conroy J. (2014) Savoring Alternative Food: School Gardens, Healthy Eating, and Visceral Difference, New York, Routledge, 207 p. Review of Agricultural, Food and Environmental Studies, 2016, 97 (3), pp.209-210. 10.1007/s41130-016-0014-5 . hal-03114832

\section{HAL Id: hal-03114832 \\ https://hal.science/hal-03114832}

Submitted on 19 Jan 2021

HAL is a multi-disciplinary open access archive for the deposit and dissemination of scientific research documents, whether they are published or not. The documents may come from teaching and research institutions in France or abroad, or from public or private research centers.
L'archive ouverte pluridisciplinaire HAL, est destinée au dépôt et à la diffusion de documents scientifiques de niveau recherche, publiés ou non, émanant des établissements d'enseignement et de recherche français ou étrangers, des laboratoires publics ou privés. 


\title{
Hayes-Conroy J. (2014) Savoring Alternative Food: School Gardens, Healthy Eating, and Visceral Difference, New York, Routledge, 207 p
}

\author{
E. Melanie DuPuis ${ }^{1}$
}

Published online: 11 May 2016

(C) INRA and Springer-Verlag France 2016

Food books today sit on two sides of a dark and wide divide: the first are the celebratory books that propound new and wonderful ways of eating and ways that can change your body, your life, and your relationship to nature and your local community; in other words, transformative books that promise to change your overall view of yourself and, subsequently, your world. These books often attack an enemy: industrial agriculture, processed food, Monsanto. The way to vanquish this enemy is to change behavior, one's own and others. In particular, these books are a cry to- as The Nation put it"wake up" oneself and others to a new way of eating. These are generally popular books written by popular writers, by chefs or by writers who belong to non-profits that take on this mission.

There is another category of food book, generally written by academics, driven by a different set of motivations. These researchers often take the first set of authors as their subjects, asking whether or not this celebration of alternative food and agriculture is effective and inclusive. Often from a frame of critical race studies or social justice, this group asks whether or not there is one alternative way to eat, or one alternative world to "wake up", where food will be "good and fair"- as Slow Food puts it - for all.

Jessica Hayes-Conroy's book is in that second category. Yet, like many authors of such books, she is not interested in tearing down a movement. She sees herself very much a part of it, but she also sees some real concerns. This look at food movements joins the work of a group of scholars, many of whom come out of the San Francisco Bay Area, who look at

E. Melanie DuPuis edupuis@pace.edu

1 Pace University, New York, NY, USA food movements from a more critical lens, not to support industrial agriculture or excuse Monsanto but to understand when the movement can meet more than the needs of a small group of people, the ones who tend to be at the average farmers market: white and middle class. She wants to explore the feelings of this group and others about food since, as she states, "Feelings are important to activism" (p. 187).

For Hayes-Conroy, the issue is viscerality. She has been working in this area for most of a decade and has carved out a unique research agenda and perspective. She looks at bodily reactions as data, a tough thing to measure but a worthwhile quest. In her work in the food movement, she finds activists teaching children to eat well in school food projects by showing them how much better "good" food tastes, that is, creating "sensory education initiatives that will magically unlock "correct' food behavior by compelling students to use their senses" (p. 10). The assumption here is that "students' sensory perception exists as a natural/essential category that is both prior to and distinguishable from their social experiences and intellectual development." In other words, food activists work on the assumption that there is one good visceral reaction to the world and that they can change behavior by showing the benefits of this universal body-world relationship.

To test this assumption, Hayes-Conroy first had to design her own tools. While most books nowadays, especially ones like this one derived from a dissertation, tend to leave out the methods section, or relegate it to an appendix, it is important to say that Hayes-Conroy's theory and methods chapters are front and center, and two of the most important chapters in the book. Defining viscerality as "the ways in which bodies come to sense and judge and (re)act," she lays down a methodology for exploring these embodied behaviors. I would hand any graduate student these chapters if he or she were going to do similar work. She supplies these chapters with quotes from her very in-depth and probing interviews - getting people to think 
about their bodily reactions to food. What she asks is, do people respond viscerally in the universal ways food activists suppose? To do this, she delves deeply into feminist theory of the body, especially ideas about relationality and performance. I was surprised that she did not draw on affect theorists such as Elspeth Probyn and Sara Ahmed, but her ideas definitely point toward this work. Also, unlike many affect scholars, HayesConroy is a field-working empiricist and she goes into the field with a theoretical toolbox that does the trick. And what she finds is that, indeed, "visceral reactions are not natural, pre-political bodily impulses" (p. 188).

In particular, Hayes-Conroy works from feminist theories of embodiment, particularly Butler's debunking of essentialist ideas of the female body. From a feminist perspective, if the body is not tied to particular natural gendered essences, why would taste be any more natural and universal? She also uses philosopher Susan Brison's work on embodiment, which shows that "social norms and identities are given material legitimacy, and also resisted, as they are (re)evaluated through conscious and subconscious bodily judgments and reactions" (p. 25).

With this in mind, Hayes-Conroy chose two case study schools, one in cosmopolitan foodie Berkeley and another in a working class community in Nova Scotia, as comparisons. She chose places with a very different politics and culture to see how the food movement fared in these two places. In Berkeley, she in particular found a viscerality of difference around race, whereas in Nova Scotia it was around class. These findings were to be expected, and a number of scholars, Rachel Slocum and Julie Guthman among them, have made similar points.

However, Hayes-Conroy goes one step beyond. These are schools, after all, and schools are a place to learn. This is where Hayes-Conroy begins to explore issues of education: the universalizing idea of good food and supposed universalist ideas that educators can teach as "correct" knowledge. What to do in a world of visceral and intellectual difference? This is Hayes-Conroy's most important achievement, one that comes from her well-formulated method: she shows how schools can be inclusive teachers of new ways to live, by providing students with "structured-yet-flexible spaces in which to negotiate their own roles in food decision making" lessons that "are significant beyond garden and cooking classrooms." In this way, education becomes a "broadening of what learning looks and feels like" (p. 189).

This is what she sees in the best of her classroom cases, where students learn new things about taste as they learn about themselves. Kitchens become places where teachers and students are in smaller groups and, in the teachers' words, "we can hang out with them more" (p. 182). Responding to the critique that alternative food spaces are "white", one school garden teacher responded, "I am also finding that some kids who come from disadvantaged neighborhoods, they really take pride in what they are creating here... I think that what is racist is actually saying that these programs are "white", because it [discounts the work that] these kids put into it" (p. 125). In the end, Hayes-Conroy finds that school food spaces are where flexibility happens, "with the novelty of the food experiences themselves - the wildness or craziness of the tastes" because the best of these pedagogies "allow(s) for and encourage(s) variation and experimentation when it is feasible to do so" (p. 189). This is the next jumping off point for studies of race and alternative food, and it would have been worthwhile to see more of this kind of discussion, especially at the end of the book.

In the end, flexibility and creativity become the partners of tolerance and respect for difference in the classroom. In part, the success of these classrooms comes from the visceralities that students bring to it and the hands-on way they learn from the teachers and from each other. Hayes-Conroy's study gives warning to the ways in which teachers through rigid ideas of good eating can fail to connect with their students but also about how a "contextual and negotiated bodied curriculum" can teach students so much more. 